\title{
Recovery of soil physical quality under repeated dryland and irrigated winter forage crops grazed by sheep or cattle
}

\author{
R.J. PATON and D.J. HOULBROOKE \\ AgResearch, Invermay Agriculture Centre, Private Bag 50034, Mosgiel, New Zealand \\ jim.paton@agresearch.co.nz
}

\begin{abstract}
There is limited research investigating the extent of soil physical damage under repeated winter forage cropping practices, the impact of management factors and the rates of soil recovery following winter grazing practices. A trial on a Fragic Pallic soil type (Aeric Fragiaquept) in the North Otago rolling down lands compared cattle versus sheep and dryland versus irrigation management. Forage crops were direct-drilled for 4 consecutive years in the following sequence: kale, swedes, triticale and kale. For this study, soil physical properties (macroporosity and bulk density) were assessed post-grazing in mid winter of 2007 following triticale grazing and again before grazing the following kale crop (Year 4) to assess soil physical recovery. Soil compaction was evident following grazing of winter forage crops with lower macroporosity measured at 0-50 mm under cattle grazing compared with sheep grazing. Recovery, particularly under cattle grazing, was evident 11 months later before the next grazing event. Therefore, natural soil recovery processes can help ameliorate the considerable soil physical damage caused by intensive animal grazing of winter forage crops.
\end{abstract}

Keywords: soil compaction, macroporosity, soil physical recovery, irrigation

\section{Introduction}

The intensive stocking of sheep and cattle on winter forage crops (often brassica such as kale or swedes) usually coincides with a period of high soil water content (Drewry \& Paton 2005; Houlbrooke et al. 2009). Intensive animal grazing in combination with high soil water contents means soil is vulnerable to physical degradation (Menneer et al. 2005; Betteridge et al. 1999; Singleton \& Addison 1999). The lack of plant cover normally afforded by permanent pasture adds further to the susceptibility. Soil damage associated with winter grazing of forage crops is typically only short term if forage crop paddocks are used as part of a pasture renewal programme and are cultivated in spring before re-establishment of pasture. However, repeated growing and grazing of winter crops established by direct-drilling has no deep mechanical alleviation of soil physical properties and recovery is reliant on natural soil processes.

The aim of this research was to investigate the potential for, and extent of, recovery of soil physical quality subsequent to grazing of repeated winter forage crops by cattle and sheep, under both irrigated and dryland management.

\section{Materials and Methods}

Forage crops were direct-drilled for four consecutive years into 16 fenced plots (approximately $10 \times 25$ m) running down a 16-18 degree slope. Crops were grazed in winter (July) each year followed by a 4-5 month fallow before establishing the following crop. This study covers the fallow period and crop growth between grazings of the third (2007) and fourth (2008) consecutive winter-grazed forage crops. In Year 3 the triticale crop was grazed in May and July. The cattle and sheep grazing the trial were both rising 1 year old with mean liveweights of 220 and $35 \mathrm{~kg}$, respectively. Cattle and sheep were stocked at approximately 280 and $2000 /$ ha, respectively, for $24 \mathrm{~h}$ by which time the available crop had been consumed. A fuller description of field methodology can be found in Houlbrooke et al. (2009). Soil sampling (0-50 mm depth) took place after the July grazing, followed by pre-grazing collection of soil bulk density and macroporosity samples 2 weeks before the Year 4 (2008) grazing of kale. Field and laboratory sampling and analysis procedures for bulk density and percentage macroporosity are described by Drewry \& Paton (2000). All data (bulk density and macroporosity) were subjected to analysis of variance, using the statistical package GenStat 10 (2007).

\section{Results and Discussion}

In Year 3, soil water content at the July grazing for the dryland and irrigated plots were 18.8 and $32.9 \% \mathrm{v} / \mathrm{v}$, respectively. The difference in macroporosity and bulk density post- and pre-grazing $(0-50 \mathrm{~mm})$ measured between years three and four showed a significant $(\mathrm{P}<0.001)$ stock type effect (Fig. 1). The measured recovery of soil physical quality following winter forage crop grazing by cattle was greater than that under sheep grazing. However, the extent of recovery under sheep-grazed plots was limited by the lower level of bulk density and higher initial measures of 
Figure 1 Soil bulk density (a) and macroporosity (b) at 0-50 $\mathrm{mm}$ depth between post-grazing of the $2007 \mathrm{crop}$ and pre-grazing of the 2008 winter forage crop. Error bar represents $\mathrm{LSD}_{5 \%}$ between treatments.

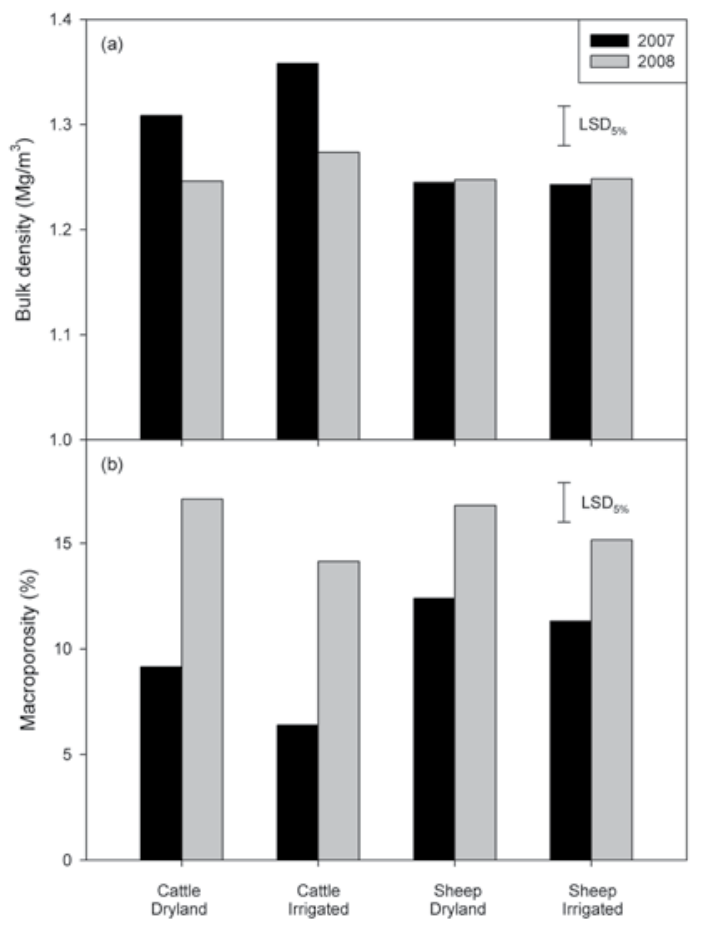

macroporosity. Following the 2007 winter crop grazing event, macroporosity recovered to similar levels for both sheep and cattle, representing a recovery of c. $9 \%$ $\mathrm{v} / \mathrm{v}$ under cattle-grazed plots and c. $4.5 \% \mathrm{v} / \mathrm{v}$ under sheep-grazed plots. Similarly, bulk density values recovered by an average $0.145 \mathrm{Mg} / \mathrm{m}^{3}$ under cattle grazed treatments and with no change in bulk density measured on sheep plots (Fig. 1). Soil macroporosity of $18 \%$ has been reported from an adjacent pastoral sheep grazed trial demonstrating that the extent of recovery measured is not to the level found under a low treading intensity farming system (Houlbrooke et al. 2006). The greater extent of soil treading damage by cattle than by sheep was probably due to the higher static loading of cattle than sheep (138 versus $66 \mathrm{kPa}$, respectively) (Greenwood \& McKenzie 2001).

A study on a similar Pallic soil in South Otago demonstrated considerable soil damage during winter forage crop grazing by cattle (Drewry \& Paton 2005). However, this study used cultivation to help ameliorate the subsequent effects of grazing animals on soil compaction. Our study relied upon natural soil recovery processes between crops that were established using direct-drilling techniques. While some studies show evidence of soil physical recovery with cessation of grazing under pasture land use (Drewry 2006), there is a paucity of studies of undisturbed soil recovery under fallow conditions in combination with direct-drilling establishment of another forage crop. It is likely that some of the same drivers of natural soil recovery under grazed pasture such as shrink and swell and freezethaw would operate under the circumstances presented in this study. The greater impact of cattle under irrigation and the smaller rebound of the soil physical properties under the irrigation treatment highlights the role drying has in restoration. The long fallow period exposing the soil aggregates to the impact of raindrops, and the limited litter inputs and root growth before the establishment of the next crop would decrease potential recovery brought about by plants and soil fauna such as earthworms.

Measurements from our research site have previously shown that the practice of continuous winter forage crop grazing that include long fallow periods and intensive animal grazing on wet soil, comes with greater risk of surface runoff losses of phosphorus and sediment (McDowell \& Houlbrooke 2009). Furthermore, soil borne diseases associated with repeated brassica crop production may limit the number of brassica crops grown.

\section{Conclusions}

Direct-drilling of winter forage crops on Pallic soils of low structural integrity reduces water and wind erosion susceptibility compared to traditional cultivation techniques. Grazing of winter forage crops at soil moisture contents close to, or above, field capacity will cause soil compaction and increase the likelihood of pugging damage. This animal treading damage will be partially alleviated by natural processes both during the ensuing fallow period and growth of the following crop. However, risks posed by soil borne disease and environmental (increased surface runoff) issues suggests that winter forage blocks should be returned to perennial pasture after 1 or 2 years to manage these risks and allow full soil physical recovery.

\section{ACKNOWLEDGEMENTS}

The authors would like to thank Grant and Elle Ludemann for the trial site, farm manager Duncan Kingan for providing stock and irrigation water and farm management advice, Sandy Harper for managing grazing and irrigation events. Special thanks to Roger Littlejohn for data analyses and graph presentation. Also thanked are Sonya Walker and Dennis Enright for field and laboratory work. The New Zealand Foundation for Research, Science and Technology is thanked for funding this research through the LUCI programme (Contract C02X0304). 


\section{REFERENCES}

Betteridge, K.; Mackay, A.D.; Shepherd, T.G; Barker, D.J.; Budding, P.J.; Devantier, B.P.; Costall, D.A. 1999. Effect of cattle and sheep treading on surface configuration of a sedimentary hill soil. Australian Journal of Soil Research 37: 743-760.

Drewry, J.J. 2006. Natural recovery of soil physical properties from treading damage of pastoral soils in New Zealand and Australia: A review. Agriculture Ecosystems \& Environment 11: 159-169.

Drewry J.J.; Paton R.J. 2005. Soil physical quality under cattle grazing of a winter fed brassica crop. Australian Journal of Soil Research 43: 525-531.

Drewry J.J.; Paton R.J. 2000. Effects of cattle treading and natural amelioration on soil physical properties and pasture under dairy farming in Southland, New Zealand. New Zealand Journal of Agricultural Research 43: 377-386.

GenStat 10 2007. 'GenStat for Windows'. Tenth Edition. VSN International Ltd, Oxford.

Greenwood K.L.; McKenzie B.M. 2001. Grazing effects on soil physical properties and the consequences for pastures: a review. Australian Journal of Experimental Agriculture 41: 1231-1250.

Houlbrooke D.J.; Paton R.J.; Morton J.D.; Littlejohn R.P. 2009. Soil quality and plant yield under dryland and irrigated winter forage crops grazed by sheep or cattle. Australian Journal of Soil Research 47: 470477.

Houlbrooke, D.J.; Morton, J.D.; Paton, R.J.; Littlejohn, R.P. 2006. The impact of land-use intensification on soil physical quality and plant yield response in the North Otago Rolling Downlands. Proceedings of the New Zealand Grassland Association 68: 165-172.

McDowell R.W.; Houlbrooke D.J. 2009. Management options to decrease phosphorus and sediment losses from irrigated cropland grazed by cattle and sheep. Soil Use and Management 25: 224-233.

Menneer J.C.; Ledgard S.F.; McLay C.D.A.; Silvester W.B. 2005. The effects of treading by dairy cows during wet soil conditions on white clover productivity, growth and morphology in a white clover-perennial ryegrass pasture. Grass and Forage Science 60: 46-58.

Singleton P.L.; Addison B. 1999. Effects of cattle treading on physical properties of three soils used for dairy farming in the Waikato, North Island, New Zealand. Australian Journal of Soil Research 37: 891-899. 